\title{
Influence of pilates and quick massage on depression, anxiety and fatigue in banking sector workers: a randomized controlled trial
}

\author{
Danillo Barbosa1, Renata Michele Angelo de Oliveira², Ivo I. Kerppers'1, Gabriela Xavier³ , Mônica Beatriz Ferreira4
}

\begin{abstract}
Background: The health of the worker is inserted within the public health, and comprises a link between production, work and health. Objectives: This study aims to analyze the influence of quick massage and pilates on the level of depression, anxiety and fatigue in employees of a bank. Method: This is a clinical, controlled, randomized, blind study. The study had 70 subjects, but only 50 were included. They were divided into 3 groups: quick massage group $(n=20)$, pilates group $(n=20)$ and control group $(n=10)$. They were evaluated in 3, 6 and 9 months and the protocol was applied 3 times per week. Results: the results were expressed as mean and standard deviation, followed by the univariate analysis of variance (ANOVA), obtaining a value of $p<0.0198$. However, it was observed, when presenting the detailed data of each group (mean and standard deviation), that the quick massage group presented a small advantage with $4.03 \pm 0.82$ ( 6 months) and $3.43 \pm 1.15$ (12 months), whereas the pilates group were $6.21 \pm 1.98016$ ( 3 months), $4.26 \pm 0.57873$ (6 months) and $4.14 \pm 0.63$ (9 months). Conclusion: it is concluded that the quick massage techniques and the Pilates protocol have shown great potential in the reduction of anxiety, depression and fatigue.
\end{abstract}

Keywords: Occupational Health; Worker Health; Pilates; Ergonomics and Manual Therapy.

\section{INTRODUCTION}

Quality of life is described, by many authors, as synonymous of health, and absence of disease ${ }^{(1)}$, and by others as a more comprehensive concept, which comprises health conditions, for example, social factors and physical, mental, psychological and emotional well-being ${ }^{(2)}$.

The construction of the quality of life in a work place, from the moment one looks to the company and the subjects as a whole, it is called a biopsychosocial approach. The biopsychosocial approach represents the differential for a diagnosis, which is service creation, campaigns and projects implementation aiming the preservation and development of people during work in the company ${ }^{(3)}$.

The health of the worker is inserted within the public health, and comprises a link between production, work and health. It starts from the principle that it is an action of work and an important part of the health-teaching process, bringing with it a reflection in which the workers are the main protagonists in this context and this contribute to a favorable work environment for the general staff(4).

In particular, the staff of the banks are undergoing profound changes over the years ${ }^{(5)}$. Such modifications are not considered good, contributing to the dissatisfaction of the workers, without development of their functions, becoming empty, monotonous and repetitive $e^{(6,7)}$.

Studies reported that improvements made in the work field contribute significantly to the increase in the quality of life and the results, increasing productivity and reducing as occupational complaints ${ }^{(8)}$. The development of activities that aim the quality of life of this group, reflects mainly in a more fraternal relationship with the clientes in the daily work ${ }^{(9,10)}$.

A quick massage, also known as chair massage ${ }^{(11)}$, is a massotherapy technique specialized in the work field, the muscle tension and the presence of painful points in the muscle according to the worker ${ }^{(12)}$. It is a detailed massage technique, which focus on the anatomy and physiology of the human body ${ }^{(13)}$. Usually uses a specific chair, which exposes the region of the neck, shoulders and upper and lower dorsum to perform the massage, with the worker (patient) sitting comfortably ${ }^{(14,15)}$.

The pilates method was devised by the German Joseph Humbert Pilates (1880-1967) during the First World War, relying on principles of Eastern culture, such as yoga, martial arts and meditation. Pilates was created in order to control the muscles involved in movement in the most conscious

Corresponding Author: Prof Dr Danillo Barbosa - danillo.barbosa@hotmail.com - +55 (35) 9-84276895. Address: Rua Lamartine Silva Paiva - 960 Condomínio Vilas do Atlântico, apartamento 102 Bairro Jardim Olímpico - Pouso Alegre - MG, Brasil. Cep: 37550-000

1 Universidade Estadual do Centro-Oeste do Paraná, Unicentro, Guarapuava, PR, Brasil

Full list of author information is available at the end of the article.

Financial support: The authors declare that there was no financial support.

Submission date 03 April 2018; Acceptance date 03 July 2018; Publication date 23 October 2018 
way possible. The six basic principles of the method are: concentration, consciousness, control, "centering, breathing, and harmonic motion ${ }^{(16)}$.

The pilates method can be performed in two main ways: on the equipment and on the ground. Considerations about method as the balance, body awareness, muscle relaxation, breathing control, stress and anxiety control, have been used as an important tool in the practice of gymnastics in

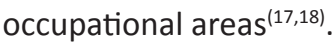

In view of the above, the central objective of the study was to evaluate the efficacy of quick massage and ground pilates on the quality of life of bankers in a private network.

\section{METHODS}

\section{Study type, place and research ethics}

This was a randomized, controlled and blinded study carried out from April to December 2017. It was developed in the physiotherapy department of the University Center of Itajubá (Fepi), together with a private banking institution in the municipality of Itajubá/MG. The project was sent to the Research Ethics Committee of the University Center of Itajubá (Fepi) with protocol number 1.045.371/ 2015.

\section{Sample Composition and Characteristics}

The study had 70 employees, who were registered according to the consolidation of labor laws (CLT), and were included outsourced employees. The sample consisted of employees of both genders, regardless of age, height, weight, socioeconomic level, schooling level or working time at the bank.

All participants signed the informed consent form, with detailed explanations of the project, as well as all phases of the project. The researchers made a brief speech to facilitate their understanding of the project, in order to clarify all the doubts of the participants wishing to participate in the study and the risks and benefits were explained with figures and posters.

The groups of the present study were divided as quick massage group ( $Q M G n=20$ ), pilates group ( $P G n=20$ ) and control group with verbal orientations and leaflets explaining posture and quality of life in work (CG $n=10)$, according Figure 1.

\section{Inclusion Criteria}

Not being subjected to any drug therapy, being a worker of the bank, having the commitment to participate in all phases of the study and signing and delivering the informed consent form.

\section{Exclusion Criteria}

Being undergoing controlled drug therapy, being a third party employee, not having the commitment to participate in all phases of the study, not signing and delivering the informed consent form.

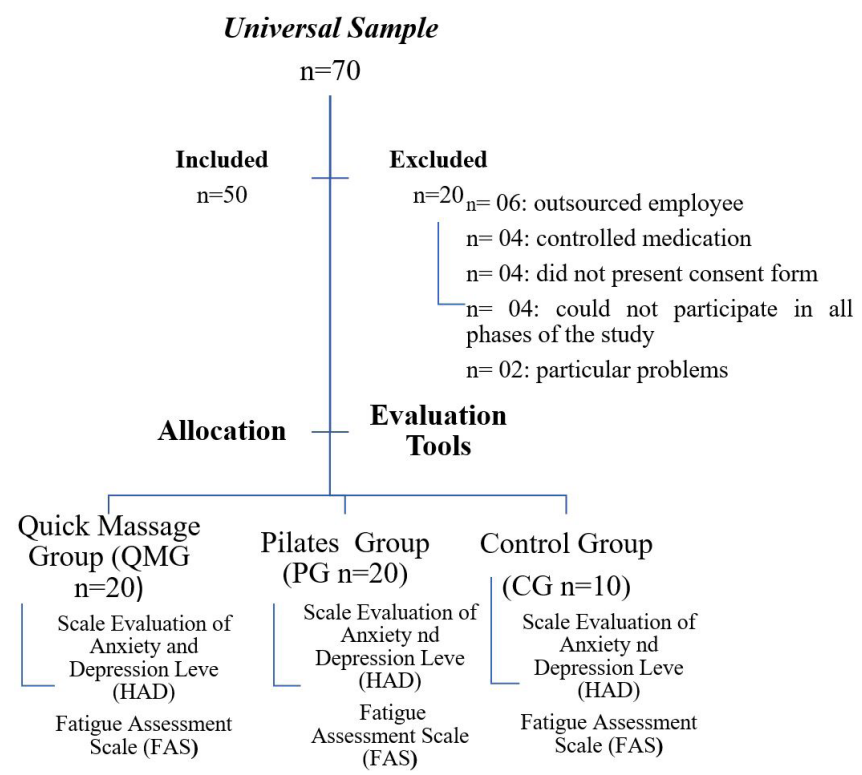

Figure 1 - Sample Distribution.

\section{Evaluation tools}

The instruments used in this study are intended to measure the direct effects that the techniques (quick massage, pilates and verbal orientations) will impact on the health of the banking worker.

\section{Scale Evaluation of Anxiety and Depression Leve (HAD).}

The HAD scale for evaluating the level of anxiety and depression is widely applied in Brazil and in the World, since it is an easy and quick instrument to be applied, and its result has high and moderate reliability and specificity to aid in the signs and symptoms of anxiety and depression.

The instrument contains 14 questions, with 4 possible answers. Each answer equals 1 point in the scoring scale. The questions related to a possible picture of anxiety are: $1,3,5,7,9,11$ and 13; and the questions related to a possible depressive picture are: $2,4,6,8,10,12$ and 14, respectively. The evaluation of the obtained points was done as follows: 0-7 points (unlikely), 8-11 points (possibly) and 12-21 points (probably) $^{(19,20)}$.

\section{Fatigue Assessment Scale (FAS).}

It is an instrument for evaluation at the level of fatigue, whose main purpose is to evaluate the individual experiencing the symptoms of fatigue in their daily life. This instrument evaluates the responses taking into account a scoring scale ranging from 1 to 5 , with high scores meaning a high level of fatigue, and low scores mean a low rate of fatigue ${ }^{(21-23)}$.

For each statement the subject must choose one of the five answer alternatives, ranging from 1 to 5 . (1= Never; $2=$ Rarely; 3 =Sometimes; $4=$ Frequently; $5=$ Always). The 10 questions on 
the instrument of fatigue are: 01. I feel bothered due to fatigue, 02 . I get tired very quickly, 03 . I do not do many things during the day, 04 . I do not have enough energy during the day and I have trouble getting things done, 07._I I have trouble thinking clearly, 08. I do not feel like doing anything, 09. I feel mentally exhausted., 10.____ I can not concentrate well when I am doing something ${ }^{(21-23)}$.

\section{Application of the Intervention Protocols}

The evaluation and intervention procedures were applied in 3 different moments with a 3-month interval between them, totaling 9 months of follow-up. The study was initiated in April 2017, when was applied the assessment and application of the evaluation instruments: $\operatorname{HAD}^{(19,20)}$ and FAS $^{(21-23)}$ were performed in the 3 groups. (Table 1 , table 2 and table 3).

Table 1 - Details of the Quick Massage techniques.

\begin{tabular}{cll}
\hline Body Region & \multicolumn{1}{c}{ Technical } & \multicolumn{1}{c}{ Repetitions } \\
\hline Head & $\begin{array}{l}\text { Pressure with thumbs in several random lines on the head, circular or transverse } \\
\text { friction at various points on the head and straightening alternating slow and } \\
\text { rapid movements throughout the circumference of the head. }\end{array}$ \\
\hline Neck & $\begin{array}{l}\text { smoothing in the cranial-caudal and caudal-cranial direction with medium } \\
\text { pressure, slight kneading with light pressure in the same directions mentioned } \\
\text { above. }\end{array}$ & $\begin{array}{l}\text { upper-to-lower trapezius thumb, upper and lower trapezius rolling and kneading, } \\
\text { upper and lower trapezius lightweight straightening. }\end{array}$ \\
\hline Shoulder & skull-caudal and cranial-to-cranial smoothing with light pressure, rolling in the \\
same direction, kneading in the same direction.
\end{tabular}

Table 2 - Details of the Pilates techniques.

\begin{tabular}{|c|c|c|c|}
\hline Exercise & Characteristics & Repetitions & Time \\
\hline One Leg Circle & $\begin{array}{l}\text { Positioned in dorsal decubitus, should maintain a slight external rotation of the hip, the } \\
\text { upper limbs should be parallel along the body, contracted abdomen, inhale and at the } \\
\text { expiration start the circumference of the right hip, which will be at } 900 \text {, will flex, abduct } \\
\text { and extend the leg. After finishing the movement, the same should be done with the } \\
\text { other leg. This exercise aims to strengthen the hip flexor and thoracic and lumbar spine, } \\
\text { assist in hip mobility, promote hip stretching and knee flexors. }\end{array}$ & $5 x$ & 5 minutes \\
\hline Shoulder Bridge & $\begin{array}{l}\text { Positioned in dorsal decubitus, with feet resting on the floor, with hip in abduction, knee } \\
\text { in flexion, upper limbs parallel to the body and abdomen in isometric contraction. Begin } \\
\text { with inspiration and when exhaling to do hip flexion unilateral and extend the leg on the } \\
\text { same side. Perform the movement on the opposite side. This exercise aims to strengthen } \\
\text { the extensors of the hip and abdomen, contributes to the movements of the spine and } \\
\text { control of the pelvic girdle. }\end{array}$ & $5 x$ & 5 minutes \\
\hline Swan Dive & $\begin{array}{l}\text { Positioned in the ventral decubitus, with the limbs parallel to the side of the body, } \\
\text { maintaining the upper limbs in adduction and elbows in flexion. Perform inspiration } \\
\text { associated with spinal hyperextension associated with elbow extension by gradually } \\
\text { raising the trunk. This exercise has the power to strengthen the spinal muscles, with } \\
\text { emphasis on the muscles of the lumbar spine, extensors of the hip and abdomen, and the } \\
\text { pelvic girdle. }\end{array}$ & $5 x$ & 5 minutes \\
\hline Neck Pull & $\begin{array}{l}\text { Positioning in dorsal decubitus, column in neutral position, hands should be behind } \\
\text { the neck, contraction of the abdomen should occur at all stages of exercise. After the } \\
\text { inspiration, perform the exhalation and flex the spine from the cervical flexing the spine } \\
\text { until you can stay in the sitting position and with hip flexion. After reaching the seated } \\
\text { position, the patient should repeat the reverse movement until he or she is in the dorsal } \\
\text { decubitus position again. This exercise aims to strengthen the abdomen, increase the } \\
\text { mobility of the spine, promote stretching of the back of the body. }\end{array}$ & $5 x$ & 5 minutes \\
\hline The Teaser & $\begin{array}{l}\text { Positioning in dorsal decubitus, with } 90 \text { o hip flexion, foot towards the ceiling, knees in } \\
\text { extension, it is important to perform the isometric contraction of the abdomen. The } \\
\text { continuation of the exercise is raising the upper limbs by flexing the shoulder, bringing } \\
\text { them behind the head, keeping the back on the floor. The purpose of this exercise is to } \\
\text { strengthen the abdomen and lower limbs, promote control of the shoulder girdle, assist } \\
\text { in the mobilization of the spine and postural control. }\end{array}$ & $5 x$ & 5 minutes \\
\hline
\end{tabular}


Table 3 - Presentation of data and comparison of groups.

\begin{tabular}{|c|c|c|c|c|c|}
\hline Tukey's Multiple Comparison Test & Mean Diff. & $q$ & Significant? $P<0.05$ ? & Summary & $95 \% \mathrm{Cl}$ of diff \\
\hline Quick Massage Group vs Pilates Group & -0.2133 & 0.3372 & No & ns & -2.959 to 2.532 \\
\hline Quick Massage Group vs Control Group (Verb Guidance) & -3.218 & 5.086 & Yes & $*$ & -5.963 to -0.4726 \\
\hline Pilates Group vs Control Group (Verb Guidance) & -3.004 & 4.749 & Yes & * & -5.750 to -0.2592 \\
\hline
\end{tabular}

Note: Quick massage group (3 months) $6.51 \pm 3.37$, ( 6 months) $4.03 \pm 0.82$, (12 months) $3.43 \pm 1.15$. Pilates group ( 3 months) $6.21 \pm 1.98016,(6$ months) $4.26 \pm 0.57873$, (9 months) $4.14 \pm 0.63$. One-way analysis of variance $P<0.0198$.

\section{Verbal guidance protocol}

The control group received only verbal guidelines on ergonomic care, postural guidelines, guidelines on mantle health and emotional balance. Guidelines were given 3 times a week, averaging 30 minutes.

\section{Data Analysis}

The data collected were initially submitted to descriptive statistical analysis, with frequency tables for categorical variables and measures of position and dispersion for continuous variables. After analysis, it were inserted into the Excel spreadsheet, in which the means and standard deviation of the HAD and FAS evaluation instruments were calculated. The data were entered into the statistical software PrismGrahpPad, in which the analysis of variance (ANOVA) and the multiple comparison between column (Turkey's) were calculated. The results were presented in tables and graph.

\section{RESULTS}

The means and standard deviation of all groups was submitted to an One-way analysis of variance, obtaining a value of $\mathrm{P}<0.0198$ and being considered significant. It was observed in the table below that the comparisons between the quick massage group and the pilates group did not present statistical difference in 3, 6 and 9 months of HAD and FAS. However, it is noted that, when presenting the detailed data of each group (mean and standard deviation), it is observed that the quick massage group has a small advantage. Quick massage group ( 3 months) $6.51 \pm 3.37$, ( 6 months) $4.03 \pm 0.82$, ( 12 months) $3.43 \pm 1.15$. Pilates group ( 3 months) $6.21 \pm 1.98016$, (6 months) $4.26 \pm 0.57873$, (9 months) $4.14 \pm 0.63$. (Figure 2 ).

It was observed that the control group, which received only verbal orientations ( 3,6 and 9 months) presented reduction of fatigue, anxiety and depression levels, but was not significant when compared to the quick massage and pilates groups.

These results corroborate the initial idea of the authors, which, supported by recent studies, observed a significant improvement in the quality of life of employees when they received some treatment or technique. Both quick massage and pilates promoted important reductions in the evaluation of HAD and FAS instruments, suggesting that such procedures could be included in the procedures applied to the quality of life at work, especially for bankers.
Scale Evaluation of Anxiety nd Depression Leve (HAD) Fatigue Assessment Scale (FAS)

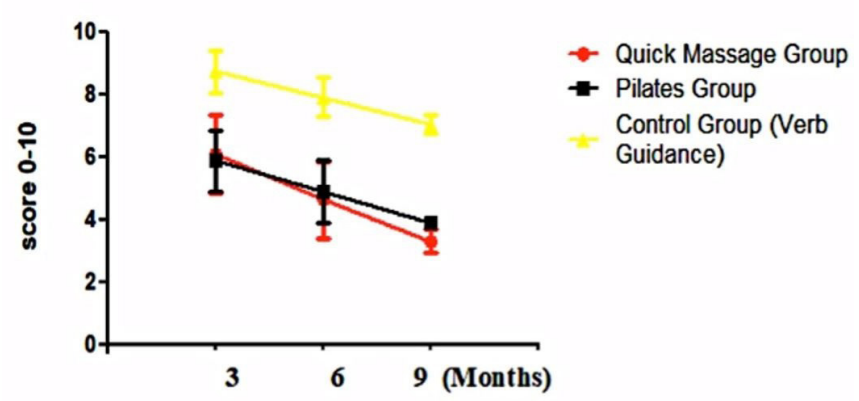

Figure 2 - Assessment of the evaluation instruments versus experimental group

\section{DISCUSSION}

Occupational stress, understood as stress at work, represents an important risk to physical and emotional well-being and has been the reason for several studies in different sectors, especially the securities agencies ${ }^{(25-29)}$.

Numerous researches have shown that excessive workload, unsatisfactory work environment, issues with a management, results-based battles, have direct reflection on the physical, mental, and social health of securities firms ${ }^{(30)}$.

An initial assessment was used to measure anxiety, depression and fatigue index, using the evaluation tools: hospital anxiety and depression scale (HAD) ${ }^{(19,20)}$ and fatigue assessment scale (FAS) ${ }^{(21-23)}$. An evaluation was performed at 3 months, 6 months and 9 months, so it was possible to measure in detail the impact of the interventions proposed in quick massage and pilates.

Another study involving bank workers ${ }^{(24)}$ analyzed the prevalence of stress as well as the main sources of this stress in the work environment. It was a cross-sectional study, performed in 2004, including state and private banks ${ }^{(24)}$. Among the events most reported as stressors in the activity and organizational environment of the bank, can be highlighted: pressure by the manager (65\%), pressure by goals $(58 \%)$, responsibility for loss of values $(47 \%)$, customer pressure (45\%), customer satisfaction (47\%), customer pressure (45\%), risk of assaults (44\%). In the evaluation of stress, it was verified that $47 \%$ of the sample had some typical symptomatology of stress. When examined separately, $15 \%$ were obtained in 
the alert phase, $46 \%$ in the resistance phase and $18 \%$ in the exhaustion phase ${ }^{(24)}$.

In the present study, it was not analyzed what causes the anxiety, depression and fatigue episodes, but the general situation of the employee who thought they were experiencing symptoms of anxiety, depression or fatigue. The applied instruments present an important and specific reliability to measure these variables. It was observed that quick massage and pilates decreased anxiety, depression and fatigue rates after the 3 evaluations according to the experimental times. The results were: quick massage group (3 months) $6.51 \pm 3.37$, (6 months) $4.03 \pm 0.82$, (12 months) $3.43 \pm 1.15$ and the pilates group ( 3 months) $6.21 \pm 1.98016$, (6 months) $4.26 \pm 0.57873$, (9 months) $4.14 \pm 0.63$.

Another study, analyzed through a systematic review, included articles related to the subject: banking, employee, depression, anxiety. This study examined in the last 10 years the main causes that bank employees reported as a potentiating agent of stress, fatigue and depression. Among the factors were: psychological harassment, feelings of loss of personal identity, physical illnesses, such as repetitive strain injuries, discrimination and suffering, anxiety, physical and mental fatigue, depression, fear, various phobias, insomnia and even suicide $^{(30)}$.

In the present study, the protocols used were based on choice, ease of execution, zero cost, practicality, speed and effectiveness of the results. Faced with this, the detailed choice of each gesture of the quick massage and each pilates exercise, was upon the complaints of the bank employees. Thus, each massage technique and each pilates exercise sought to promote physical, psychic and social wellness, as well as directly contribute to the improvement of work productivity, interpersonal relationship and even promote important body changes, such as increased flexibility and decrease of tension throughout the body ${ }^{(30)}$.

\section{CONCLUSIONS}

In view of the findings, it was observed that the interventions performed with pilates and quick massage presented a potential to reduce the signs and symptoms of depression, anxiety and fatigue in bank employees. It is suggested that other studies be performed by increasing the time of exercise application, and analyzing the sample for a period of more than 12 months.

\section{AUTHORS' CONTRIBUTION}

DB: data collection, statistical analysis and reviewed the final article; RMAO: monitoring the application of the protocol in the banking agencies, and application of the evaluation instruments; IIK: reviewed the charts, the statistical analysis and the text in English; GX: monitoring the application of the protocol in the banking agencies and application of the evaluation instruments; MBF: reviewed the charts, the statistical analysis and the text in English.

\section{CONFLICT OF INTEREST}

The authors declare that there was no conflict of interest.

\section{AUTHORS DETAILS}

${ }^{2}$ Centro Universitário de Itajubá, Itajubá, MG, Brasil. ${ }^{3}$ Universidade Federal de Alfenas (Unifal), Alfenas/MG, Brasil. ${ }^{4}$ Centro Universitário do Sul de Minas Gerais (Unis), Varginha, MG, Brasil.

\section{REFERENCES}

1. Fleck MPA, Xavier SLM, Chachamoich E, Vieira G, Santos L, et al. Aplicação da versão em português do instrumento de avaliação de qualidade de vida da Organização Mundial da Saúde (WHOQOL-100). Rev Saúde Pública. 2000; 34:(2) 178-83.

2. Pereira EF, Teixeira CS, Santos A. Qualidade de vida: abordagens, conceitos e avaliação. Rev. bras. Educ. Fís. Esporte. 2012; 26(2): 241-50.

3. Gonçalves, A, Gutierrez GL, Vilarta R. (Org.). Gestão da Qualidade de Vida na Empresa. Campinas: IPES Editorial; 2005. p 189-90.

4. Mendes R, Dias EC. Da Medicina do Trabalho à Saúde do Trabalhador. Rev. Saúde Pública. 1991; 25(5): 341-9.

5. Merlo, AR, Barbarini, N. Reestruturação produtiva no setor bancário brasileiro e sofrimento dos caixas executivos: um estudo de caso. Psicologia \& Sociedade. 2002; 14(1): 103-122.

6. Codo, W, Sampaio, JJC. Síndrome do trabalho vazio entre bancários. Jornal Bras. de Psiquiatria. 1993;13:23-8.

7. Falqueto, MGFB. Construção social da identidade bancária: o que é ser bancário? Simpósio de saúde mental e trabalho bancário. 1997 Maio 0912; VITÓRIA (ES): Universidade Federal do Espírito Santo, 1997. p 15-18.

8. Nadler DA, Lawler EE. Quality of work life: perspectives and directions. Winter, Organ Dyn. 1983;11:20-30.

9. Moulin MGB. Trabalho, gênero e saúde mental: modos de inserção da mulher no trabalho bancário. Rio de Janeiro: Universidade Federal do Rio de Janeiro, 1996 (Dissertação de Mestrado em Psicossociologia de Comunidades e Ecologia Social). 1996. p 22-28.

10. Assunção AA. A saúde bancária na era moderna: fatores de risco - saúde no trabalho bancário. São Paulo, Central Única dos Trabalhadores; 1993.

11. Cassar MP. Manual de massagem terapêutica: um guia completo de massoterapia para o estudante e para o terapeuta. São Paulo: Manole; 2001.

12. Domenico G, Wood EC. Técnicas de Massagem de Beard. 4oㅡ. Editora Manole - São Paulo; 1998.

13. Moretti A, Lima V. Massagem no Ambiente do Trabalho. 1‥Ed. São Paulo: Phorte; 2010.

14. Rogel CSP, Resi AL, Oliveira MG. Quick Massage no centro de saúde: uma proposta de cuidado e promoção de saúde para profissionais da atenção primária. Belo Horizonte; 2013. p. 19-22. p.1562-65.

15. Silva ST, Cynthia MR. Quick Massage e os seus benefícios relacionados ao ambiente de trabalho. Rev. Saúde Pública. 2013;22: 11-18.

16. Sacco ICN, Andrade MS, Souza PS, Nisiyama M, Cantuária AL, Maeda FYI, et al. Método Pilates em revista: aspectos biomecânicoa de movimentos específicos para reestruturação postural - Estudos de caso. Rev. Bras. Ciência e Movimento. 2005; 13(4): 65-78.

17. Miranda LB, Morais PDC. Efeitos do método Pilates sobre a composição corporal e flexibilidade. Rev. Bras. de Prescrição e Fisiologia do exercício. 2012; 3(13): 16-21.

18. Mares G, Oliveira KB, Piazza MC, Preis C, Neto LB. A importância da estabilização central no método Pilates: uma revisão sistemática. Fisioter. Mov. 2012; 25(2):445-451.

19. Zigmond, AS7, Snaith, RP. The Hospital Anxiety and Depression Scale.Acta Psychiatrica Scandinavica. 1983; 67(1): 361-370.

20. Botega NJ, Bio MR, Zomignani MA, Garcia JR C, Pereira WAB. Transtornos do humor em enfermaria de clínica médica e validação de escala de medida (HAD) de ansiedade e depressão. Rev. de Saúde Pública. 1995; 29(5): 355-63.

21. Drent M, Lower EE, De Vries J. Sarcoidosis-associated fatigue. Eur Respir J. $2012 ; 40(1): 255-263$. 
22. Kleijn WPE, De Vries J, Wijnen PAHM, Drent M. Minimal (clinically) important differences for the Fatigue Assessment Scale in sarcoidosis. Respir Med. 2011; 105(1): 1388-95.

23. De Vries, Michielsen H, Van Heck GL, Drent M. Measuring fatigue in sarcoidosis: the Fatigue Assessment Scale (FAS). Br J Health Psychol 2004; 9(1): 279-91.

24. Koltermann AP, Koltermann IT, Tomasi E, Horta Estresse ocupacional em trabalhadores bancários: prevalência e fatores associados. Saúde. 2011; $7(2): 3348$.

25. Seifert AM, Messing K, Dumais L. Star wars and strategic defense initiatives: work activity and healty symptoms of unionized bank tellers during work reorganization. Inter. Journal of Health Services. 1997; 27(3):45577-79.
26. Sousa FM, Messing K, Menezes PR, Cho HJ. Chronic fatigue among bank workers in Brazil. Occupation Medicine (Lond). 2002; 52(4):18794-95.

27. Palacios M, Duarte F, Câmara VM. Trabalho e sofrimento psíquico de caixas de agências bancárias na cidade do Rio de Janeiro. Cad Saúde Pública. 2002;18(3):84351-55.

28. Donato YB, Almeida EM, Diniz EM. Caracterização dos níveis de stress em bancários da cidade de João Pessoa PB. Anais I Congresso Norte Nordeste de Psicologia. V Semana Baiana de Psicologia. Salvador. Bahia. 1999;22-9.

29. Nunes NA, Molina FB, Zola TRP, Lauris JRP, Nunes OBC. Avaliação do nível de estresse emocional em bancários de Cafelândia/SP e percepção de sintomas bucais. Rev. Fac. Odontol. Lins, Piracicab. 2005;17(1):2332-35.

30. Sousa FM, Messing K, Menezes PR, Cho HJ. Chronic fatigue among bank workers in Brazil. Occupation Medicine (Lond). 2002; 52(4):18794-99. 